\title{
Understanding of Earthquake Damage Pattern through Geomorphological Approach: A Case Study of 2006 Earthquake in Bantul, Yogyakarta, Indonesia
}

\author{
Dwi Wahyuni Nurwihastuti' ${ }^{1}$ Junun Sartohadi' ${ }^{2}$, Djati Mardiatno ${ }^{2}$, Udo Nehren ${ }^{3}$, Restu1 \\ ${ }^{1}$ Department of Geography, State University of Medan, Medan, Indonesia \\ ${ }^{2}$ Faculty of Geography, Gadjah Mada University, Yogyakarta, Indonesia \\ ${ }^{3}$ Institute for Technology and Resources Management in the Tropics and Subtropics, Cologne University of \\ Aplied Sciences, Cologne, Germany \\ Email: nurwihastuti@gmail.com
}

Received May 2014

\section{Abstract}

The last major earthquake in Bantul causing severe damage occurred on May $27^{\text {th }}, 2006$. The damages in the flat area of Bantul had a certain pattern. The damages pattern controlled the subsurface characteristic below the flat area. Understanding earthquake damage pattern through geomorphological approach is important for earthquake hazard analysis. The techniques of remote sensing and Geographical Information Systems were applied to analyze earthquake damage pattern and geomorphological characteristics. Gravity analysis was used to identify the subsurface structure and the basement depth while geoelectric analysis was used to identify sediment depth. Moreover, spatial correlation analysis was used to identify the relationship between the earthquake damage, geomorphological characteristics, and subsurface characteristics. The results show that fluvial, marine, and aeolian landforms have low rock density value based on gravity analysis. These indicate that they were composed by thick unconsolidated material of quaternary alluvium. While denudational, structural, and solutional landforms composed by material of tertiary rocks have high rock density value. The severe damage occurred in the area that has a lower value of local gravity and deeper basement. In contrast, the slight damage occurred in the area that has higher values of local gravity and shallower basement. Moreover, the severe damage occurred in areas of thicker sediment that consist of unconsolidated material. Consequently, the area of unconsolidated material that has deeper basement and thicker sediment is prone to earthquake. They were located on fluvial, marine, and aeolian landforms.

\section{Keywords}

Earthquake Damage Pattern, Geomorphology, Subsurface Characteristic 


\section{Introduction}

Indonesia has a lot of earthquakes because the Indonesian Archipelago is a result of the collision of three main tectonic plates: 1) the Eurasian plate, 2) the Indian Ocean-Australian plate, and 3) the oceanic West Pacific plate [1]. Minster and Jordan (1978) in (Verstappen, 2000) [1] described that the Southeast Asian plate moves 1 $\mathrm{cm} /$ year south — eastward, the Indian Ocean-Australian plate $7 \mathrm{~cm} /$ year northward and the West Pacific plate 9 $\mathrm{cm} /$ year westward. Moreover, the Indian Ocean-Australian plate subducts at a rate of $6-7 \mathrm{~cm} /$ year beneath Sumatra and Java Islands as parts of the Eurasian plate [2]-[4]. This convergent plate boundary dominates tectonic and volcanic processes as subduction zones. Consequently, the collision of those three major tectonic plates affects Indonesia that is located in a very active earthquake region.

The Indonesian earthquake created serious damage in many places in Java, e.g. the Bantul earthquake that happened in Java Island on May $27^{\text {th }}$, 2006. Bantul is located in Yogyakarta Special Province, Java Island, Indonesia, as presented in Figure 1. The 2006 earthquake in Bantul caused severe damage. The earthquake damage pattern is unique in the flat area of Bantul. The damage pattern is related to the pattern of sediment thickness, while the surface of the alluvial plain looks homogenous. Identification of subsurface condition through detail surface characterization is becoming a challenge. This study aims to get a better understanding of the earthquake damage pattern and the correlation with the subsurface characteristics, which is of utmost importance for earthquake hazard prediction as well as land use and settlement planning.

\section{Method}

Some techniques of remote sensing and Geographical Information Systems were applied to analyze earthquake damage pattern and geomorphological characteristic. The earthquake damage pattern was obtained from visual interpretation of IKONOS after 2006 earthquake and secondary data of damage. The geomorphological characteristic was obtained from visual interpretation of ASTER and field observation. Furthermore, geophysical techniques were applied to analyze subsurface characteristics, i.e. geoelectric and gravity analyses. Geoelectric analysis was applied to obtain sediment thickness and material type. It was supported by drilling data. Gravity analysis applied Bouguer Anomaly Map to identify the subsurface structure and the basement depth. The first step is the conversion from Bouguer Anomaly Map to digital data. The digital data of Bouguer Anomaly must be projected onto flat areas. The next step is separation of local anomaly and regional anomaly using upward continuation. The local anomaly and geological information were applied to make subsurface modeling. This step produces subsurface structure. Moreover, spatial correlation analysis was used to identify the relationship between the earthquake damage, geomorphological characteristics, and subsurface characteristics.

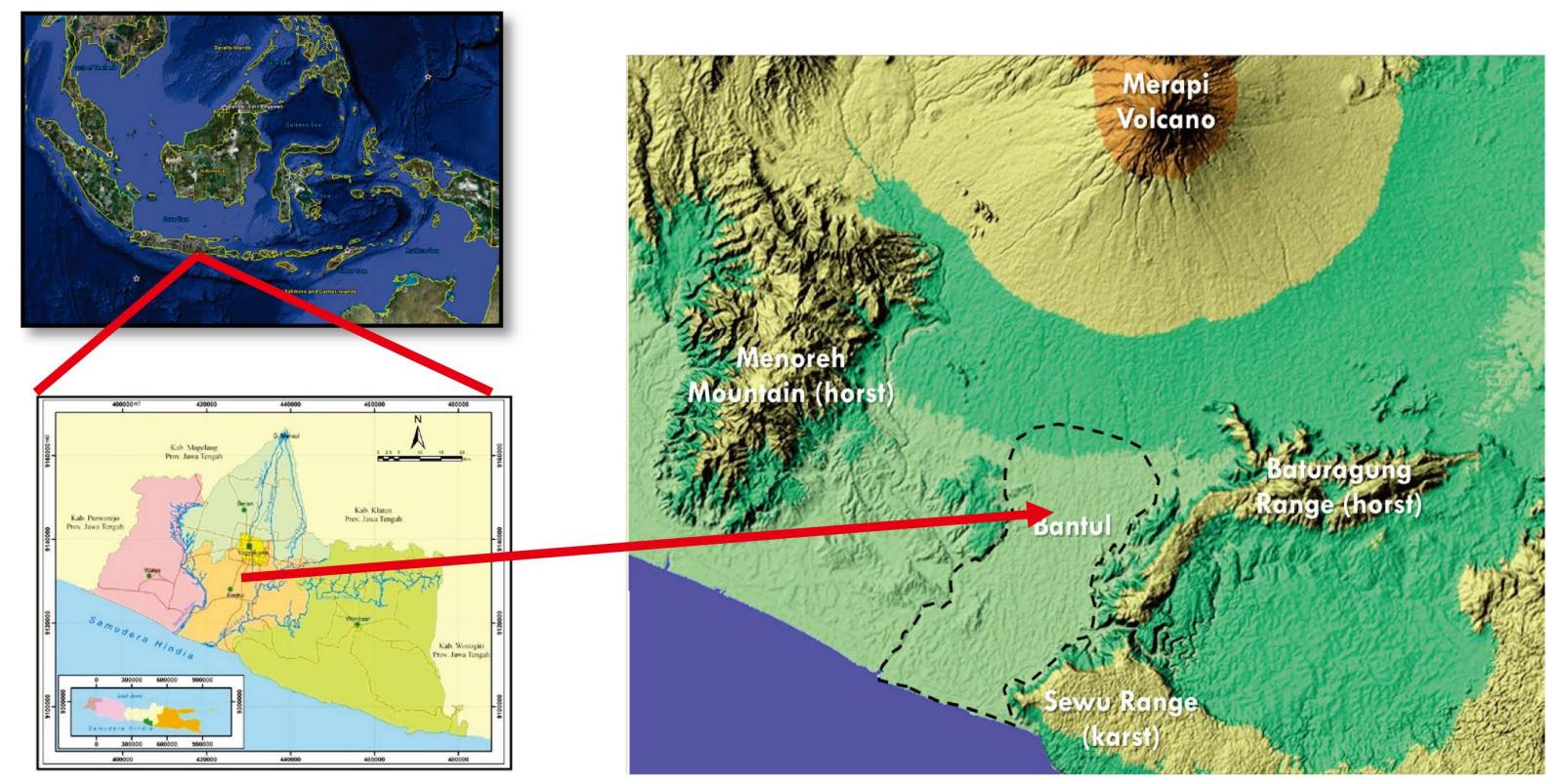

Figure 1. Bantul is located in Yogyakarta Special Province, Java Island, Indonesia. 


\section{Results and Discussion}

\subsection{Earthquake Damage Pattern of Bantul}

The 2006 earthquake in Bantul caused a lot of damage. According to International Recovery Platform (IRP) (2009) [5] and Bappenas (2006) [6], more than 1.1 million people in the provinces of Yogyakarta and Central Java were affected by this earthquake. The victim indicated 5716 confirmed deaths and 37,927 survivors with severe injuries. The damage was very heavily concentrated on the housing sector with $52.48 \%$ damages.

Bantul area is the most destroyed areas due to 2006 earthquake. According to Pemerintah Provinsi DIY \& Pemerintah Provinsi Jawa Tengah (2006) and Pemerintah Provinsi DIY (2006) [7], the victims are 223,117 households which consist of 779,287 people with 4143 people dead. Furthermore, the houses damaged are 71,763 collapses, 71,372 heavily damaged and 73,669 slightly damaged. Consequently, the Bantul area is earthquake prone areas.

The areas of damage due to 2006 earthquake were covered Yogyakarta Province and part of Central Java Province. Bantul is the most severe damage and many casualties. The damage occurred in the plains area. According to Yamazaki and Matsuoka (2007) [8], Subdistrict of Pundong, Bambanglipuro, Jetis, and Pleret is an area that has the highest ratio of house damage (75\% - 100\%), while Piyungan Subdistrict having 50\% - 75\% damage ratio. Subdistrict of Imogiri, Sewon, Bantul, Pajangan, and Banguntapan suffered damage ratio of 25\% 50\%, while Subdistrict of Dlingo, Sedayu, Kasihan, Kretek, Sanden, Srandakan, and Pandak suffered only damage ratios from $12.5 \%$ - 25\%. In additional, the intensive damage zone extends for $18 \mathrm{~km}$ in the North-South direction along Subdistrict of Pleret, Jetis, and Pundong with total collapse rate over $60 \%$ and the human loss rate over $1.6 \%$ [9].

The detail spatial distribution of damage due to 2006 earthquake is focused in Bantul Lowland. The damage only focuses on the settlement area. The criteria of damage based on classification of building damage as qualitatively. There are 3 classes of damage, i.e. severely damage, moderately damage, and slightly damage. The damage was determined based on interpretation of IKONOS imagery, secondary data, and field check. The earthquake occurred on 27 May 2006, so field checks used interviews with community and identify the former damage and the residual damage. Table 1 provides the percentage of earthquake damage in Bantul District. Figure 2 illustrates the detail spatial distribution of damage in Bantul District.

\subsection{Geomorphological Characteristics}

Geomorphological characteristics cover geomorphological aspects and landform. Geomorphological aspects consist of morphology, morphogenesis, morphochronology and morphoarrangement [10]. Morphology in Bantul was interpreted based on digital elevation models (DEM) of SRTM (Shuttle Radar Topographic Mapping Mission). SRTM data are useful for large geographic areas [11], such as Bantul. The elevation of Bantul has a range from $0 \mathrm{~m}$ to $507 \mathrm{~m}$ above mean sea level. The low point had been located at along the coastline of the Bantul coastal area. While the highest point is located at the Baturagung Range, i.e. Sudimoro Mountain in Mangunan Village, Dlingo Sub District. The morphology of Bantul can be classified in plain, hill, and mountain.

The process of landform composing is closely connected to the genesis or morphogenesis. Genesis is the Greek word for origin or creation and in geomorphology the term relates to the origin of a landform, in other words the process responsible for the creation of the form [12]. Thus, morphogenesis is the geomorphological aspect that related to the origin and development of landform. Morphogenesis can be detailed into passive morphostructure, active morphostructure, and morphodynamic. Passive morphostructure is related to lithology, both rock types and structures while the active morphostructure is related to endogenous dynamics that contain tectonic events during the landform formation. The passive morphostructure that was found in the Bantul are faults, lineaments, escarpments and anticline. The passive and active morphostructure of Bantul is presented in the surface lithological map. Morphodynamic is related to exogenous dynamics. Morphodynamic of Bantul is caused by water and wind that consist of several types. There are mass movements including soil erosion, sedimentation caused by water and sand deposits caused by wind. Mass movements including soil erosion were occurred in the hills and mountain areas in Bantul. Sedimentation was occurring along rivers in Bantul, especially the main river, i.e. Progo River and Opak River. The sand deposits caused by wind were occurring along coastal areas in Bantul.

Morphochronology is describing absolute and relative dating of landforms and related processes. Morphochronology in the Bantul area was analyzed refers to the relative dating of landforms and related processes, e.g. 
Table 1. The percentage of earthquake damage in Bantul.

\begin{tabular}{cclcc}
\hline \multirow{2}{*}{ No. } & $\begin{array}{c}\text { Earthquake } \\
\text { Damage }\end{array}$ & \multicolumn{1}{c}{ Corresponding Areas } & \multicolumn{2}{c}{ Area } \\
\cline { 3 - 5 } 1 & Slightly & $\begin{array}{l}\text { All area of Kasihan, Pajangan, Kretek, Srandakan, Sanden, Sedayu, and Dlingo } \\
\text { Subdistrict } \\
\text { Hill and mountain area of Piyungan, Pleret, Imogiri, and Pundong Subdistrict }\end{array}$ & 331.20 & 60.37 \\
2 & Moderately & All area of Pandak Subdistrict & 24.47 & 4.75 \\
3 & Severely & $\begin{array}{l}\text { All area of Sewon, Jetis, Banguntapan, Bantul, and Bambanglipuro Subdistrict } \\
\text { Plain area of Piyungan, Pleret, Imogiri, and Pundong Subdistrict } \\
\text { Total Area of Bantul }\end{array}$ & 179.82 & 34.88 \\
& & 515.49 & 100.00 \\
\hline
\end{tabular}

Source: Data analysis result (2013)

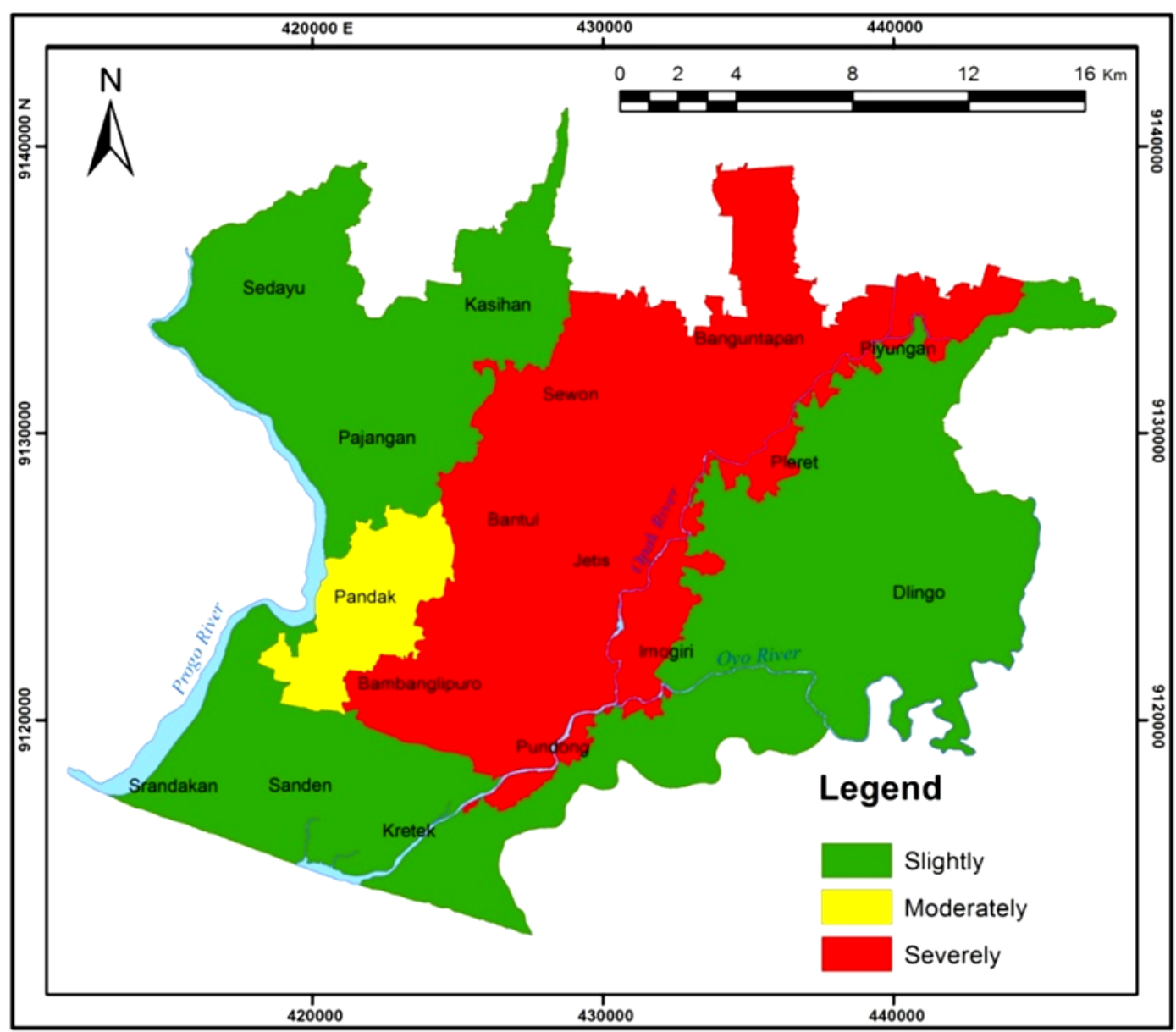

Figure 2. The detail spatial distribution of damage in Bantul District.

young beach ridge and old beach ridge. The young beach ridge was created after the old beach ridge. The landforms that located close to the coast are the younger landforms, because of the active processes of wave in the coast. Furthermore, the landforms that located close to the river are the younger landforms, because of the active processes of water flow in the river. In addition, morphochronology is also describing the genesis of each landform.

Morphoarrangement is describing the spatial arrangements and interrelationships of various landforms and processes. Hilly and mountain areas can be divided into peak, upper slope, middle slope, lower slope and foot slope plain based on morphoarrangement. Alluvial plains also can be divided into natural levee and flood plain based on morphoarrangement. Natural levees were located along river and they have more higher relief compare 
the surrounding areas. Flood plains were located in the back of the natural levees that have lower relief compare the surrounding areas. The general landforms of the Bantul area consist of 6 landforms based on their genesis. They are fluvial landform, marin landform, aeolian landform, solutional landform, denudational landform and structural landform. Moreover, there are 48 detail landforms.

\subsection{Subsurface Characteristics}

Sunsurface characteristics in this study cover lithological characteristics, paleo-sedimentation processe, and schematic past relief pattern in Bantul. Stratigraphically, the lithology of Bantul from older to younger consist of Semilir Formation (Tmse), Nglanggran Formation (Tmn), Sambipitu Formation (Tms), Sentolo Formation (Tmps), Wonosari Formation (Tmwl) and Quaternary deposits. Generally, Bantul was composed by two lithological controls that were very different, i.e. Quaternary deposits and Tertiary rocks. Quaternary deposits were composed of sand deposits as a product of Merapi Volcano and clay deposits as a result of Tertiary rock weathering. While the Tertiary rocks was divided into Tertiary igneous rocks and Tertiary sedimentary rocks. Moreover, Tertiary igneous rocks were composed by Semilir Formation, Nglanggran Formation and Sambipitu Formation. Otherwise, the Tertiary sedimentary rocks were composed by Wonosari Formation and Sentolo Formation.

Semilir Formation consists of interbedded tuff-breccia, pumice breccia, dacite tuff, andesite tuff and tuffaceous claystone of Upper Oligocene-Lower Miocene. Nglanggran Formation consists of volcanic breccia, flow breccia, agglomerate, lava and tuff of Lower Miocene. In addition, Smyth et al. (2005; 2008) [13] [14] mention the Semilir and Nglanggran Formations form part of sequence of volcanic and volcaniclastic rocks that are exposed over a large area. They were deposited in a very short time period, at most about one million years. Furthermore, Smyth et al. (2008) [14] mention that Semilir eruption occurred in Lower Miocene.

Sambipitu Formation consists of tuff, shale, siltstone, sandstone and conglomerate of Middle Miocene. Wonosari Formation consists of coral reef limestone, calcarenite and tuffaceous calcarenite of Upper MioceneUpper Pliocene. Sentolo Formation consists of limestone and marly sandstone of Middle Miocene-Upper Pliocene. It spreads along the low hills surrounding Progo River, in the western and eastern of Progo River. Moreover, McDonald and Partners (1984) [15] divided Sentolo Formation into 3 kinds, namely Sentolo-1, Sentolo-2 and Sentolo-3. The Sentolo-1 consists of marls, tuffs and conglomerates. The Sentolo-2 consists of marly limestones and calcarenites. The Sentolo-3 consists of bedded limestones.

The structure of Bantul and its surrounding are strongly influenced by plate tectonic movement between the Eurasian plate and the Indian-Australian plate. Bantul is a part of Yogyakarta Basin. The geological structure of Yogyakarta Basin is a graben. It confined by two faults, Progo River fault on the west and Opak River fault bordered Southern Mountains to the east. These faults were interpreted from the gravity pattern [16]. The Yogyakarta Basin is mostly covered by Young Merapi sediments that consist of tuff, volcanic ash, breccias, agglomerate and lava of Quaternary age [17]. The thickness of the sediment is up to $100 \mathrm{~m}$ [18]. The other sediments are river and coastal sediments. River and coastal sediments consist of gravel, sand, silt and clay of Holocene age [19]. Fault system in this area is interpreted as a buried fault [15] [19].

Paleo-sedimentation is a sedimentation that occurred at the past time. Paleo-sedimentation in Bantul Lowland can be identified based on material of sedimentation result. The material of sedimentation contained information about earth surface environments in the past. The material of sedimentation result can be identified based on geoelectric data and drilling data.

The geoelectric data provide the resistivity of constituent material of Bantul area. Based on the resistivity values, it can know the constituent material of Bantul area. In order to obtain the kind of materials, it is necessary the geological map to support interpretation of geoelectric data.

Based on the geoelectric analysis, it can know that the material of Bantul Lowland was covered by alluvium. It proved that fluvial processes have been working in this area. The fluvial processes consist of transportation and sedimentation. The thickness of alluvium reached $150 \mathrm{~m}$ based on the geoelectric analysis. This thick alluvium indicates that the sedimentation occurs repeatedly. The geoelectric analysis results can be confirmed by the analysis of drilling data.

There are 52 points of drilling data throughout Bantul Lowland. The depths vary from $20 \mathrm{~m}$ to $150 \mathrm{~m}$. Generally, the composition of the sediment is unconsolidated material that derived from Merapi Volcano. They consist of sand, gravel, clay, and silt. In some borehole data, there are breccias layers. They proved that the material de- 
rived from fluvial processes. It is characterized by repetition of sand units that were dominant with grain size from fine to coarse: silt, clay, in some places the sand-gravel mixture and breccias. The repetition layers such as these show that the areas have been repetitive sedimentation process caused by lifting and decline both by tectonic processes and by past sedimentation in the Bantul basin.

Past relief showed the relief in an area in the past. The past relief is reflected based on the basement of Bantul Lowland which consists of Tertiary materials. The basement of Bantul Lowland has been analyzed using gravity information that used as a way to predict the geological structure and the density of the rocks making up the Earth's crust. According to Widijono and Subagio (2009) [20], gravity anomaly distribution plays an important role to determine the distribution of rocks and geological structures below the surface that is covered by Quaternary sediments. Widijono and Subagio (2009) [20] also stated that the straightness of Bouguer anomaly is thought to be a response to the gravity of the regional structural lineament. Moreover, based on the contour map of gravity also can be derived basement depths [20] [21]. The highs and lows in the Bouguer gravity anomalies were interpreted as basement highs and lows [21].

The gravity analysis applied Bouguer Anomaly Map of The Yogyakarta Quadrangle Java by Marzuki and Otong (1991) [22] which was published by Geological Research and Development Centre, Directorate General Geology and Mineral Resources, Department of Mines Energy. Bouguer anomaly map is a gravity anomaly map that reflects the spreading pattern of rock density.

The Bouguer Anomaly map was analyzed to get the local or residual gravity anomaly map. The analysis is performed in Yogyakarta, Bantul and the surrounding area. The values of local gravity anomaly in Yogyakarta and its surrounding area are varied from $-12.9 \mathrm{mGal}$ up to $+15.9 \mathrm{mGal}$ as presented in Figure 3 .

The value of local gravity anomaly was interpreted to know subsurface structure. The striking differences in local gravity anomaly value and the straightness of local gravity anomaly reflect any fault in that area. The negative value of local gravity anomaly indicated that the area has low rock density. The low rock density indicated
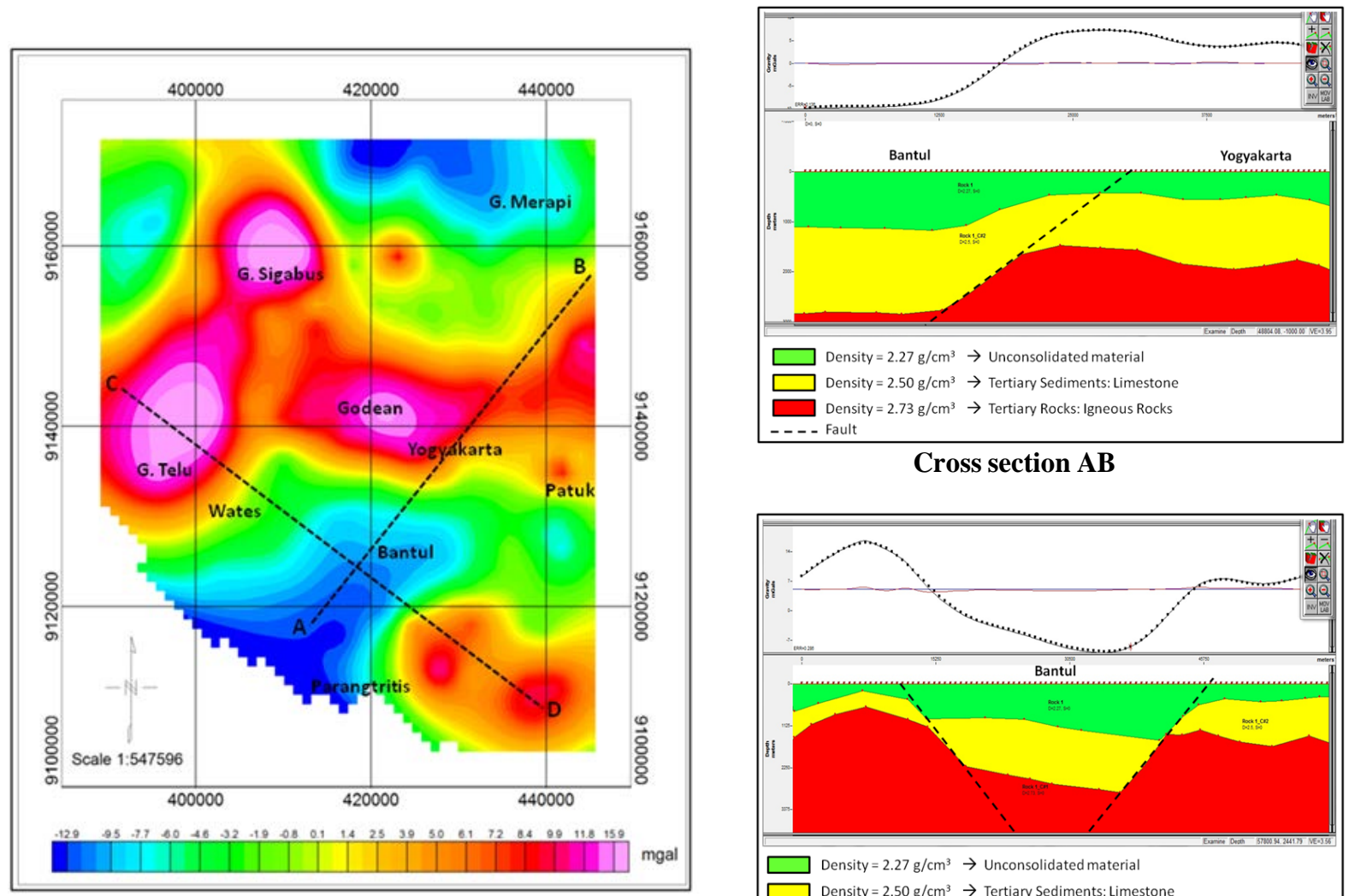

\section{Cross section AB}

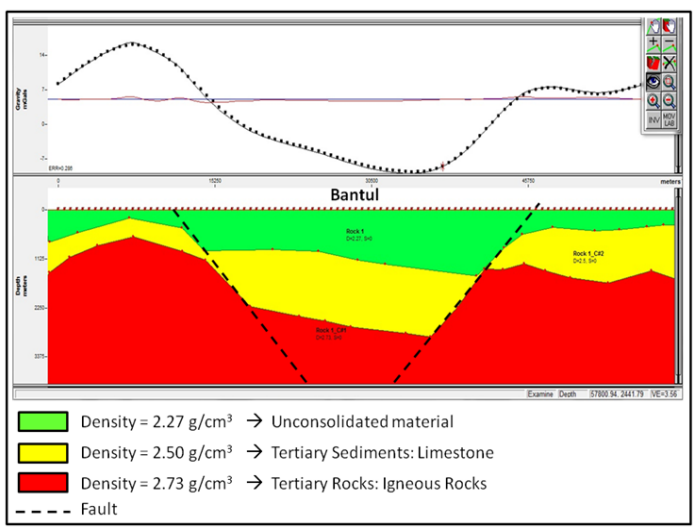

Cross section CD

Figure 3. The local or the residual gravity anomaly of Yogyakarta and its surrounding area. 
that the area consists of unconsolidated material. On the other hand, the positive value of local gravity anomaly indicated that the area has higher rock density. The higher rock density indicated that the area consists of Tertiary sediments and Tertiary rocks.

There are 3 kinds of rocks based on the rock density in Yogyakarta, Bantul and the surrounding area. They are unconsolidated material, Tertiary sediments (limestone) and Tertiary rocks (igneous rocks). The rock density of unconsolidated material is $2.0-2.27 \mathrm{~g} / \mathrm{cm}^{3}$. The rock density of Tertiary sediments (limestone) is $2.5 \mathrm{~g} / \mathrm{cm}^{3}$. The rock density of Tertiary rocks (igneous rocks) is $2.73-2.80 \mathrm{~g} / \mathrm{cm}^{3}$. Based on the subsurface modeling, it indicated that there is a buried fault between Yogyakarta and Bantul and a graben structure in Bantul area.

Based on the cross section of subsurface modeling in the some part of Bantul Lowland, it can be interpreted that the geological structure of Bantul is asymmetry graben. The eastern part of graben is deeper than the western part of graben. The basement depth of graben varies up to $1.6 \mathrm{~km}$. These results are consistent with studies of Fukuoka et al. (2008) [23], Setijadji et al. (2008) [24], and Daryono (2011) [25]. Bantul Lowland is a part of Yogyakarta Basin. Fukuoka et al. (2008) [23] have been delineated the density structure of the Yogyakarta Basin. The result shows that there is $30-40 \mathrm{~km}$ wide and more than $2 \mathrm{~km}$ deep graben structure in the Yogyakarta Basin. According to Setijadji et al. (2008) [24], Yogyakarta Basin is a half-graben structures that deeper at its eastern margin. Moreover, Daryono (2011) [25] stated that resonance frequency data of microtremor measurements can describe the profiles of graben bedrock depth qualitative, so it is known that the Bantul Graben is not a symmetrical graben type with the bedrock more depth in the eastern.

The past relief pattern in Bantul Lowland now was covered by sediment material. The sediment depth of Bantul Lowland can be identified from drilling data and geoelectric data. Based on the analysis of drilling data and geoelectric data, it can conclude the sediment in the Bantul area varied from $3 \mathrm{~m}$ up to $150 \mathrm{~m}$. The deepest sediment conducts in the eastern part of Bantul Lowland. The deeper sediment is close to the escarpment of Baturagung Range. While the shallower sediment close to Sentolo hill and Sentolo isolated hill. This fact indicates that the basement of Bantul Lowland is not flat but sloping and irregular. The deeper basement occurred in the eastern part. Otherwise, the shallower basement occurred in the western part.

\subsection{Correlation of Earthquake Damage Pattern, Geomorphological Characteristic and Subsurface Characteristic}

The severely damage due to 2006 earthquake occurred in area of fluvial landform. The spatial correlation between earthquake damage pattern and subsurface characteristic was divided into the spatial correlation between: earthquake damage pattern and basement depth, earthquake damage pattern and sediment thickness, earthquake damage pattern and material type. The results of spatial correlation between earthquake damage pattern and subsurface characteristics were described as follows:

1) Generally, the severely damage occurred in the area that have a lower value of local gravity and deeper basement. In contrast, the slightly damage occurred in the area that have higher values of local gravity and shallower basement.

2) The severely damage occurred in areas of thicker sediment. Based on statistical analysis of Spearman rank correlation, the correlation coefficient between earthquake damage pattern and sediment thickness is 0.707 (strong correlation). It means the thicker sediment the more damage. On the other hand, the thinner sediment the less damage.

3) The severely damage occurred in area of unconsolidated material. This fact indicates that the area of unconsolidated material is prone to earthquake.

The results of spatial correlation between earthquake damage pattern and sediment thickness are accordance with the research result of Naing (2010) [26] and Karnawati et al. (2008) [27]. According to Naing (2010) [26], the thick sediment area has strong effects on amplification characteristics and high amplification zones relatively coincide with high damage areas during the 2006 earthquake. Additionally, Karnawati et al. (2008) [27] mention that the most susceptible zone of earthquake was the area which consists of the thickest sediment.

Moreover, the results of spatial correlation between earthquake damage pattern and material type indicate that the area of unconsolidated material is prone to earthquake. On the other hand, the area of consolidated material is the area of earthquake safety. According to Karnawati et al. (2008) [27], the most susceptible zone of the earthquake was the area in Bantul which consist of the loosest gravelly sand-silty sand of Recent Opak-Oya River deposits. Fukuoka et al. (2008) [23] also mention that the damaged area due to 2006 earthquake occurred in Bantul area that consists of unconsolidated soil. While, Walter et al. (2008) [28] mention that earthquake 


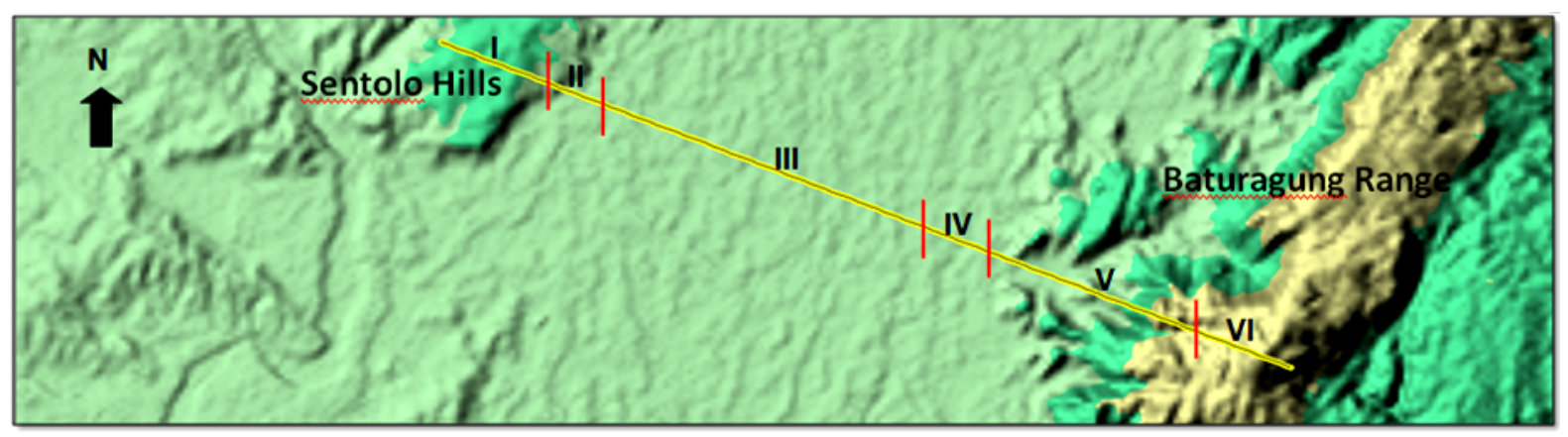

\begin{tabular}{|c|c|c|c|c|c|c|}
\hline \multicolumn{5}{|c|}{ From Pos: $7^{\prime} 52^{\prime} 16.3313^{\circ}$ S, $110^{\prime} 17^{\prime} 21.532 l^{\prime \prime}$ E } & \multicolumn{2}{|c|}{ To Pos: $7^{\prime} 55^{\prime} 39.9089^{\prime \prime} \mathrm{S}, 110^{\circ} 26^{\prime} 12.3890^{\circ} \mathrm{E}$} \\
\hline \multicolumn{7}{|c|}{$500 \mathrm{~m}$} \\
\hline & $2.5 \mathrm{~km}$ & $5.0 \mathrm{~km}$ & $7.5 \mathrm{~km}$ & $.0 \mathrm{~km}$ & $12.5 \mathrm{~km}$ & $15.0 \mathrm{~km}$ \\
\hline & I & II & III & IV & $\mathbf{V}$ & VI \\
\hline & Pajangan & Pandak & Bantul, Jetis & Imogiri & Imogiri & Imogiri \\
\hline Earthquake damage & Slightly & Moderately & Severely & Severely & Slightly & Slightly \\
\hline Basement depth & Shallow & Deep & Deeper & Deepest & Shallow & Shallow \\
\hline - Gravity anomaly & High & Low & Low & Low & High & High \\
\hline Sediment thickness & Thin & Thick & Thicker & Thickest & Thin & Thin \\
\hline Material type & Consolidated material & $\begin{array}{l}\text { Unconsolidated } \\
\text { material }\end{array}$ & Unconsolidatedmaterial & $\begin{array}{l}\text { Unconsolidated } \\
\text { material }\end{array}$ & Consolidated material & Consolidated material \\
\hline
\end{tabular}

Figure 4. A Cross section shows the correlation between earthquake damage pattern and subsurface characteristics.

damage occupied in an area of weak sediments. In the other case, Sato et al. (2004) [29] state that the severely damage due to 2003 Colima (Mexico) earthquake occurred in plain areas that consist of soft sediment. Moreover, Pidwirny (2009) [30] mentions that unconsolidated materials have a tendency to increase the amplitude and duration of the seismic waves increasing the potential for damage. Figure 4 illustrates a cross section shows the correlation between earthquake damage and subsurface characteristics in Bantul.

\section{Conclusion}

There are correlation between earthquake damage pattern, geomorphological characteristic, and subsurface characteristic. The severe damages occurred in area that has deep basement, low gravity anomaly, thick sediment, and unconsolidated material. On the other hand, the slight damages occurred in area that have shallow basement, high gravity anomaly, thin sediment, and consolidated material. They are located on fluvial landform.

\section{References}

[1] Verstappen, H.Th. (2000) Outline of the Geomorphology of Indonesia: A Case Study on Tropical Geomorphology of a Techtogene Region. ITC Publication, Number 79, Enschede.

[2] Tregoning, P., Brunner, F.K., Bock, Y., Puntodewo, S.S.O., McCaffrey, R., Genrich, J.F., Calais, E., Rais, J. and Subarya, C. (1994) First Geodetic Measurement of Convergence across the Java Trench. Geophysical Research Letters, 21, 2135-2138. http://dx.doi.org/10.1029/94GL01856

[3] McCaffrey, R. (1996) Asia Slip Partitioning at Convergent Plate Boundaries of SE. Geological Society, London, Special Publications, No. 106, 3-18. http://dx.doi.org/10.1144/GSL.SP.1996.106.01.02

[4] Kato, T., Ito, T., Abidin, H.Z. and Agustan (2007) Preliminary Report on Crustal Deformation Surveys and Tsunami Measurements Caused by the July 17, 2006 South off Java Island Earthquake and Tsunami, Indonesia. Earth Planets Space, 59, 1055-1059. http://dx.doi.org/10.1186/BF03352046

[5] International Recovery Platform (2009) The Yogyakarta and Central Java Earthquake 2006. Recovery Status Report, Volume I.

[6] Bappenas (2006) Preliminary Damage and Loss Assessment, Yogyakarta and Central Java Natural Disaster: A Joint Report of BAPPENAS, the Provincial and Local Governments of D. I. Yogyakarta, the Provincial and Local Governments of Central Java, and International Partners. The 15th Meeting of the Consultative Group on Indonesia (CGI) Jakarta, 14 June 2006, Jakarta, 140 p.

[7] Pemerintah Provinsi DIY \& Pemerintah Provinsi Jawa Tengah (2006) ATLAS Kawasan Gempa Bumi 27 Mei 2006. 
Pemerintah Provinsi DIY dan Pemerintah Provinsi Jawa Tengah, Yogyakarta.

[8] Yamazaki, F. and Matsuoka, M. (2012) Remote Sensing Tools for Earthquake Response and Recovery. International Symposium on Remote Sensing Applications to Natural Hazards.

http://www.gwu.edu/ spi/assets/docs/Yamazaki\%20\%20Remote\%20Sensing\%20Tools\%20for\%20Earthquake.pdf

[9] Murakami, H., Pramitasari, D. and Ohno, R. (2008) Human Casualty and Damage Distribution in Relation to Seismic Intensity in The 2006 Central Java Earthquake in Indonesia. The 14th World Conference on Earthquake Engineering, 12-17 October 2008, Beijing.

[10] Van Zuidam, R.A. (1985) Aerial Photo-Interpretation Terrain Analysis and Geomorphology Mapping. Smits Publishers, The Hague, $442 \mathrm{p}$.

[11] Bishop, M.P., James, L.A., Shroder Jr., J.F. and Walsh, S.J. (2012) Geospatial Technologies and Digital Geomorphological Mapping: Concepts, Issues and Research. Geomorphology, 137, 5-26. http://people.cas.sc.edu/ajames/Research/Pubs/12\%20Bishop\%20et\%20al.pdf. http://dx.doi.org/10.1016/j.geomorph.2011.06.027

[12] Gustavsson, M. (2005) Development of a Detailed Geomorphological Mapping System and GIS Geodatabase in Sweden, Chapters 1-4: Review of Geomorphological Mapping. Licentiate Thesis, May 2005.

[13] Smyth, H., Hall, R., Hamilton, J. and Kinny, P. (2005) East Java: Cenozoic Basins, Volcanoes and Ancient Basement, Proceedings, Indonesian Petroleum Association, Thirtieth Annual Convention \& Exhibition, August 2005.

[14] Smyth, H.R., Hall, R. and Nichols, G.J. (2008) Cenozoic Volcanic Arc History of East Java, Indonesia: The Stratigraphic Record of Eruptions on an Active Continental Margin. In Draut, A.E., Clift, P.D. and Scholl, D.W., Eds., Formation and Applications of the Sedimentary Record in Arc Collision Zones: Geological Society of America Special Paper 436, 199-222.

[15] McDonald and Partners (1984) Greather Yogyakarta Groundwater Resources Study, Volume 3: Groundwater: Government of the Republic Indonesia, Ministry of Public Works, Directorate General of Groundwater Resources Development Groundwater, Development Project (P2AT).

[16] Untung, M., Udjang, K. and Ruswandi, E. (1973) Gayaberat di daerah Yogyakarta, Wonosari, Jawa Tengah (Gravity Survey in the Yogyakarta, Wonosari Area, Central Java), Geological Survey of Indonesia. Publikasi Teknik seri Geofisika, No. 3, 7 h.

[17] van Bemmelen, R.W. (1970) The Geology of Indonesia. 2nd Edition, Martinus Nijhoff, The Hague.

[18] Pramumijoyo, S. and Sudarno, I. (2008) Surface Cracking Due to Yogyakarta Earthquake 2006. In: Karnawati, D., Pramumijoyo, S., Anderson, R. and Husein, S., Eds., The Yogyakarta Earthquake of May 27, 2006, Star Publisher, Los Angeles (in Press).

[19] Rahardjo, W., Sukandarrumidi and Rosidi, H.M.D. (1995) Geological Map of the Yogyakarta Sheet, Jawa, Scale 1:100.000. Geological Research and Development Centre, Bandung.

[20] Widijono, B.S., dan Subagio (2009) Anomali Gaya Berat Sebagai Salah Satu Petunjuk Keterdapatan Gejala Struktur Geologi Daerah Jogjakarta dan sekitarnya, Prosiding Workshop Geologi Pegunungan Selatan 2007, Publikasi Khusus No. 38, ISBN 978-979-551-019-2, Pusat Survei Geologi, Departemen Energi dan Sumber Daya Mineral Bandung, Indonesia.

[21] Barros, L.V. and Assumpcao, M. (2011) Basement Depths in the Parecis Basin (Amazon) with Receiver Functions from Small Local Earthquakes in the Porto Dos Gaúchos Seismic Zone. Journal of South American Earth Sciences, 32, 142-151.

[22] Marzuki and Otong (1991) Bouguer Anomaly Map of The Yogyakarta Quadrangle Java, Geological Research and Development Centre, Directorate General Geology and Mineral Resources, Department of Mines Energy.

[23] Fukuoka, K., Ehara, S., Fujimitsu, Y., Udi, H., Setyawan, A., Setijadji, L.D., Harijoko, A., Pramumijoyo, S., Setiadi, Y. and Wahyudi (2008) Interpretation of the 27 May 2006 Yogyakarta Earthquake Hypocenter and Subsurface Structure Deduced from the Aftershock and Gravity Data. In: Karnawati, D., Pramumijoyo, S., Anderson, R. and Husein, S., Eds., The Yogyakarta Earthquake of May 27, 2006, Star Publisher, Los Angeles (in Press).

[24] Setijadji, L.D., Watanabe, K., Barianto, D.H., Rahardjo, W., Sudarno, I., Susilo, A. and Itaya, T. (2008) Searching for the Active Fault of the Yogyakarta Earthquake of 2006 Using Data Integration on Aftershocks, Cenozoic Geo-History, and Tectonic Geomorphology. In: Karnawati, D., Pramumijoyo, S., Anderson, R. and Husein, S., Eds., The Yogyakarta Earthquake of May 27, 2006, Star Publisher, Los Angeles (in Press).

[25] Daryono (2011) Indeks Kerentanan Seismik berdasarkan Mikrotremor pada Setiap Satuan Bentuklahan di Zona Graben Bantul Daerah Istimewa Yogyakarta, Disertasi, Program Pascasarjana Fakultas Geografi, Universitas Gadjah Mada, Yogyakarta.

[26] Naing, T. (2010) Analysis of Microtremors for Site Amplification Characteristics and Ground Motion in Yogyakarta, Indonesia, Dissertation, Faculty of Engineering, Gadjah Mada University. 
[27] Karnawati, D., Husein, S., Pramumijoyo, S., Ratdomopurbo, A., Watanabe, K. and Anderson, R. (2008) Earthquake Microzonation and Hazard Maps of the Bantul Area, Yogyakarta, Indonesia. In Karnawati, D., Pramumijoyo, S., Anderson, R. and Husein, S., Eds., The Yogyakarta Earthquake of May 27, 2006. Star Publisher, Los Angeles (in Press).

[28] Walter, T.R., Luehr, B.G., Wang, R., Sobiesiak, M., Grosser, H., Wetzel, H.U., Milkereit, C., Zschau, J., Wassermann, J., Harjadi, P. and Brotopuspito, K.S. (2008) The 26 May 2006 6.4 Yogyakarta Earthquake South of Mt. Merapi Volcano: Did Lahar Deposits Amplify Ground Shaking and thus Lead to Disaster? Geochemistry, Geophysics, Geosystems. An Electronic Journal of the Earth System. http://www.volcanotectonics.de/publications.html

[29] Sato, T., Nakamura, Y. and Saita, J. (2004) Evaluation of The Amplification Characteristics of Subsurface Using Microtremor and Strong Motion: The Studies at Mexico City. 13th World Conference on Earthquake Engineering, Paper No. 862, Vancouver, BC, Canada.

[30] Pidwirny, M. (2010) Earthquakes. Fundamentals of Physical Geography. 2nd Edition. http://www.physicalgeography.net/ fundamentals/10m.html 